\title{
Indoor air quality assessment and its impact on health in context to the household conditions in Lucknow
}

\author{
Lawrence A.J. ${ }^{1 *}$, Khan T. ${ }^{2}$ and Azad I. ${ }^{2}$ \\ ${ }^{1}$ Department of Chemistry, Isabella Thoburn College, Lucknow, U.P., 226007, India \\ 2Department of Chemistry, Integral University, Lucknow, U.P., 226026, India \\ Received: 12/03/2019, Accepted: 30/07/2019, Available online: 22/10/2019 \\ *to whom all correspondence should be addressed: e-mail: alfredlawrence16@yahoo.com \\ https://doi.org/10.30955/gnj.003105
}

\begin{abstract}
To assess the indoor air quality of urban and rural houses of Lucknow region, the present study was conducted from November 2014 to October 2015. Concentrations of $\mathrm{SO}_{2}$, $\mathrm{NO}_{2}, \mathrm{CO}_{2}, \mathrm{CO}, \mathrm{NH}_{3}, \mathrm{H}_{2} \mathrm{~S}, \mathrm{PM}_{10}$ and $\mathrm{PM}_{2.5}$ were measured in five urban and five rural houses. House selection was done after a questionnaire survey in two medical colleges. The average concentrations of $\mathrm{PM}_{10}\left(280\right.$ and $315 \mu \mathrm{g} \mathrm{m}^{-3}$ ) and $\mathrm{PM}_{2.5}\left(185\right.$ and $\left.210 \mu \mathrm{g} \mathrm{m}^{-3}\right)$ were highest in the winter season. Excessive consumption of crude fuel to combat cold conditions was associated with high particulate concentrations in rural houses. Smoking was observed as a common indoor habit. Skin irritation was a common symptom reported during rainy season whereas complaints of cataract, cough and sneezing were prevalent in winter season. Air quality index with respect to particulate concentration was predicted by three different methods and found to be poorest in rural houses during winter season with values 716.1, 457.0 and 7.427 respectively.
\end{abstract}

Keywords: Indoor air, questionnaire, monitoring, health, crude fuel.

\section{Introduction}

The 2016 Environmental Performance Index placed India at $141^{\text {th }}$ position out of the 180 countries surveyed, thereby highlighting the poor environmental quality of the country (Environmental Performance Index, 2016). According to the report's findings, more than 3.5 billion people worldwide are exposed to unsafe air quality which includes $75 \%$ of India's population. The actual exposure to air pollutants should include all micro-environments where a person spends time (Lawrence, Masih and Taneja, 2005). Indoor air pollution (IAP) is a direct consequence of outdoor contamination. In developing countries IAP is designated as one of the four most serious universal ecological problems (Mac, 2009). Indoor air pollution can be ten times more than the ambient air pollution (Kankaria, Nongkynrih and Gupta, 2014). From time to time, different studies have highlighted the deteriorating environmental conditions in India in both the urban and the rural set ups. Though, the magnitude of the problem is different in both the environments. Due to lack of long term studies in India, there is still a need of strategic actions and implementations (Garaga and Kota, 2018). There is also an uncertainty related to emitting sources (Garaga and Kota, 2018). Very few studies have correlated the adverse health effects with the exposure of pollution (Thurston and Balmes, 2017). Though the urban and rural population is equally susceptible to the exposure of air pollution, yet the sources are different and need to be addressed in independent manner. Marked socioeconomic differences exist between the urban and rural areas, but the air pollution assessment studies in India have more or less been focused on urban environment (Garaga and Kota, 2018). Hence, the assessment of nationwide pollution exposure is very difficult. The fact can be elaborated by taking into account of particulate concentration and distribution. According to a report on global air pollution by WHO, it was indicated that 13 of the world's 20 cities with the highest annual concentrations of PM2.5 belong to India. Increasing industrialization and economic development are supposed to be the major stakeholders in urban centres whereas, usage of solid biomass is held responsible for the alarmingly high particulate concentration in rural set ups. Approximately $76 \%$ of rural households rely on crude fuel for different household activities and are susceptible to the exposure to household air pollution (Balakrishnan et al., 2015). Hence the spectrum of exposures to local sources like biomass cooking, garbage burning and small industrial waste emission contribute to large spatial gradients in exposures that need to be studied and understood at regional levels (Pant, Guttikunda and Peltier, 2016). Contribution of household air pollution may be uneven in urban and rural settings and to estimate accurate health impact more extensive exposureresponse studies are needed and it is expected that the studies might vary between the two environments. There are substantial gaps in monitoring studies across the country, especially in rural locales (http://www.cpcb.nic.in/RealTimeAirQualityData.php).

This study is an attempt to present the scenario of indoor 
pollution in urban and rural houses in Lucknow region in terms of household characteristics, including the fuel choices. The findings also identified the health issues related to the exposure of IAP. To address the issue minutely, the study area was further subdivided into several microenvironments based on traffic distribution, architectural aspects and surroundings.

\section{Materials and methods}

\subsection{Basis of site selection}

The severity of the problem of pollution is different for urban and rural environments. In cities it is largely associated with rapid urbanization and industrialization (Banerjee and Srivastava, 2011). Open garbage dumping and burning also leads to the emission of toxic air pollutants in urban environment such as particulates, carbon monoxide, black carbon, dioxins, furans and mercury (Rees, 2011). In rural environment, dependence on crude and unprocessed fuel for cooking and other activities is still very much prevalent owing to limited access to electricity and other non-polluting energy sources which may be due to economic underdevelopment and poor infrastructure. Due to the existing differences in living conditions, the urban and rural set ups were identified as the two environments for the study. Lucknow covers geographical area of $310 \mathrm{Sq}$. $\mathrm{km}$ and is one of the major cities of India, it was empirical to further sub-divide the urban region in different microenvironments. The classification was based on population distribution, traffic density and architectural pattern of the households and most importantly, the frequency of health symptoms reported by the respondents.
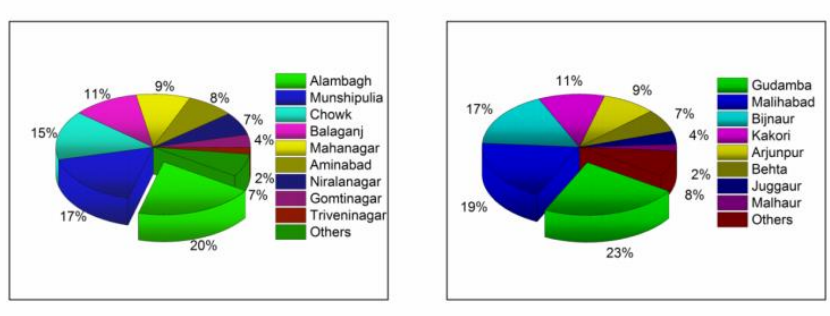

Figure 1. (a) Percentage distribution of patients from urban localities. (b) Percentage distribution of patients from rural localities

Lucknow $\left(26^{\circ} 51^{\prime} \mathrm{N}\right.$ and $\left.80^{\circ} 55^{\prime} \mathrm{E}\right)$ is located at the bank of river Gomti with total population of 2815033 (Lawrence and Fatima, 2014). Many small villages are situated at the periphery of the main city. Household selection for the indoor air quality assessment was done with the help of a questionnaire survey. A questionnaire survey was done with respiratory patients in two medical colleges. The questionnaire was prepared with the help of pulmonary disease experts. Questions pertaining to daily time/activity diary, daily indoor and outdoor activity pattern and household characteristics were included in the questionnaire. Different activities such as cooking, cleaning, heating, number of occupants and surroundings of house were also included in the questionnaire. Another important aspect of the study was to assess health symptoms of inhabitants as related to indoor air quality. In all 971 patients were interviewed in the survey. For rural patients a respondent was hired to mark the answers. Top five localities to which the majority of patients belonged were selected for indoor air quality assessment (Figure $1 \mathrm{a}$ and $1 \mathrm{~b}$ ). House characteristics were recorded by the respondent. Usually the questions were directed to the women present in the houses as they spend majority of the time indoors. Personal observation and focus group discussion methods were also used to collect information regarding household characteristics and nearby surroundings. Meteorological data (Average temperature, wind speed, wind direction and average rainfall) was collected from Lucknow weather station during the sampling period. Schematic representation of house selection is given as Figure 2. The selected urban sites on the basis of survey were Aalambagh, Munshipulia, Chowk, Balaganj and Mahanagar, whereas the rural sites selected for the study were, Malihabad, Bijnaur, Kakori and Arjunpur respectively. The site characteristics have been given in Table 1. Average wind speed recorded was $47 \mathrm{~km} \mathrm{~h}^{-1}, 41 \mathrm{~km} \mathrm{~h}^{-1}$ and $31 \mathrm{~km} \mathrm{~h}^{-1}$ respectively in summer, monsoon and winter seasons. Average temperature in summer, rainy and winter season was $36.5{ }^{\circ} \mathrm{C}, 34.25{ }^{\circ} \mathrm{C}$ and $22.7{ }^{\circ} \mathrm{C}$ respectively. While house selection it was made sure that no potent pollution sources like factories and brick kilns etc. were present in the vicinity of $10 \mathrm{~km}$.

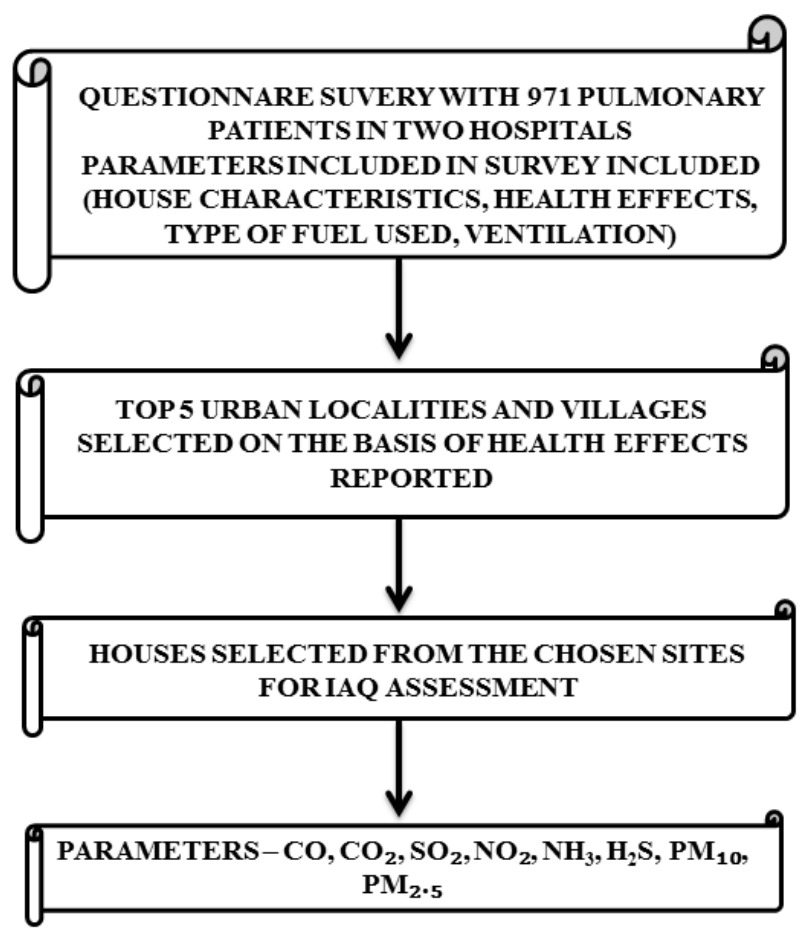

Figure 2. Schematic representation of house selection 
Table 1. Characteristics of urban and rural microenvironments

$\begin{array}{cc}\text { Microenvironment } & \text { Sampling site } \\ \text { Urban } & \text { Alambagh }\end{array}$

\section{Site description}

Residential as well as commercial area. Heavy traffic flow $24 \mathrm{~h}$. In day time there was heavy rush due to intercity buses, three wheelers, two wheelers and

passenger cars. During night there is movement of trucks and long distance buses. Diesel engine driven vehicles are also prominent. There are a number of small-scale industries as well.

Munshipulia $\quad$ Active roadside activities during day time mainly from buses, trucks and light motor vehicles.

Chowk Busy area with old commercial shops and congested houses. The area was residential cum commercial. Tempos, two wheelers and cars' movement is observed throughout the day. The whole area had narrow lanes

\begin{tabular}{|c|c|c|}
\hline & Balaganj & $\begin{array}{l}\text { Bus and truck flow mainly in daytime. A small livestock with } 5 \text { to } 6 \text { buffalos was } \\
\text { located near the area. No proper drainage was there for animal waste }\end{array}$ \\
\hline & Mahanagar & $\begin{array}{c}\text { Proper new houses with adequate ventilation. Low traffic flow. Mainly light } \\
\text { vehicular traffic. }\end{array}$ \\
\hline \multirow[t]{5}{*}{ Rural } & Gudamba & $\begin{array}{l}\text { Very underdeveloped village with kachcha, semi-pakka houses with one room. } \\
\text { Houses usually made of mud and grasses. }\end{array}$ \\
\hline & Malihabad & $\begin{array}{l}\text { Mango belt of north India. Houses are usually semi-pakka with large } \\
\text { courtyards. Low traffic density and sufficient greenery around. }\end{array}$ \\
\hline & Bijnaur & $\begin{array}{c}\text { Houses were either kachcha (uncemented)- made up of locally available natural } \\
\text { building material like bamboo, thatch wood reeds, leaves, grasses or sticks or } \\
\text { semi pakka- using mud or thatch to construct walls and roofs. Dusty roads } \\
\text { marked the outer environment. }\end{array}$ \\
\hline & Kakori & $\begin{array}{l}\text { Houses made of mud, grass and bamboo. Low traffic, roads mainly of mud and } \\
\text { concrete with loads of greenery around. }\end{array}$ \\
\hline & Arjunpur & Houses made of mud, khaprail, grasses and bamboos. \\
\hline
\end{tabular}

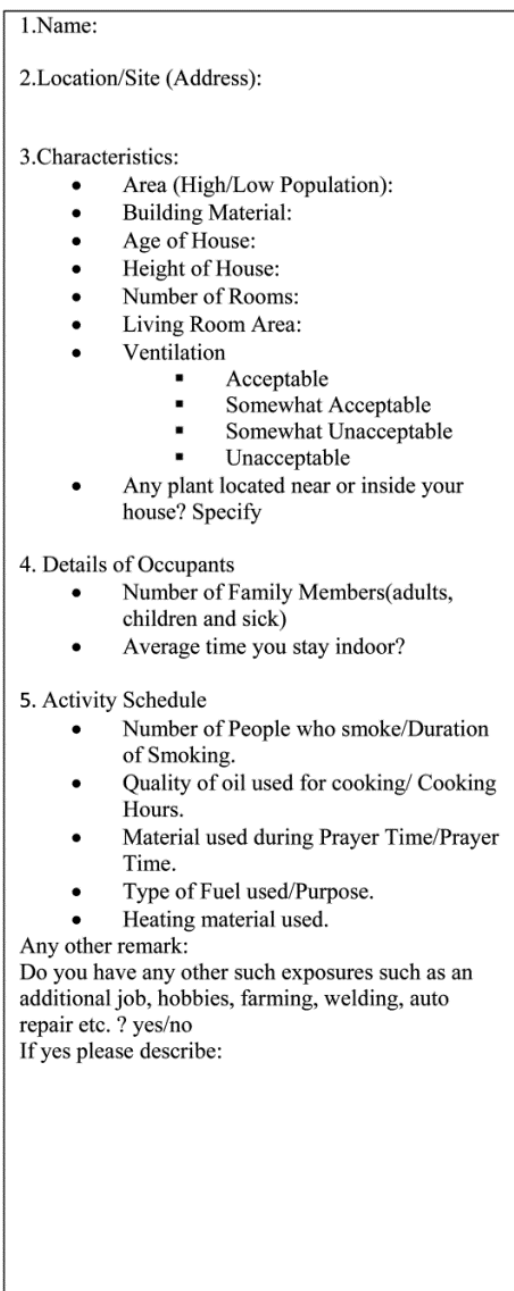

6. Health Status
$\begin{aligned} & \text { 6.1 What health complaints you have experienced? } \\
& \text { Select any symptoms you have experienced in your home. (This is random } \\
& \text { list - not all symptoms listed have been noted in houses.) }\end{aligned}$
\begin{tabular}{|l|l|l|l|l|}
\hline \multicolumn{1}{|c|}{ SYMPTOMS } & OCCASIONALLY & FREQUENTLY & \multicolumn{1}{c|}{$\begin{array}{c}\text { NOT } \\
\text { RELATED } \\
\text { TO } \\
\text { HOUSE }\end{array}$} & NO \\
\hline $\begin{array}{l}\text { Difficulty in } \\
\text { Concentrating }\end{array}$ & & & & \\
\hline Dry or sore throat & & & & \\
\hline Dizziness & & & & \\
\hline Itching & & & & \\
\hline Heartburn & & & & \\
\hline Nausea & & & & \\
\hline Noticeable Odours & & & & \\
\hline Sinus Congestion & & & & \\
\hline High stress levels & & & & \\
\hline Chest tightness & & & & \\
\hline Eye irritation & & & & \\
\hline Hyperventilation & & & & \\
\hline $\begin{array}{l}\text { Shortness of } \\
\text { breadth }\end{array}$ & & & & \\
\hline Headache & & & & \\
\hline Fatigue/drowsiness & & & & \\
\hline $\begin{array}{l}\text { Temperature too } \\
\text { hot }\end{array}$ & & & & \\
\hline $\begin{array}{l}\text { Temperature too } \\
\text { cold }\end{array}$ & & & & \\
\hline
\end{tabular}

6.2 Are the symptoms more likely to appear at particular times of the day/year?

6.3 Do these symptoms clear up within 1-2 hours after leaving house? Yes/No

If no, do they clear up overnight or over the weekend? Yes/No 6.4 Have you sought medical attention for your symptoms? Yes/No If yes, please specify the medicines taken routinely.

6.5 Do you have any allergies or other health problems that may account for any of the listed symptoms? Yes/No. If yes, please describe:

6.6 Can you offer any other commentsor observations that may be helpful in determining the environmental condition of your home? 


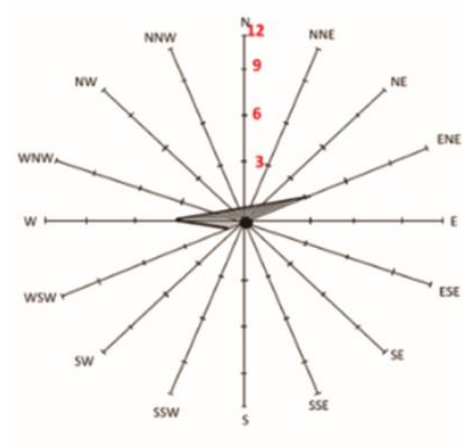

November 2014

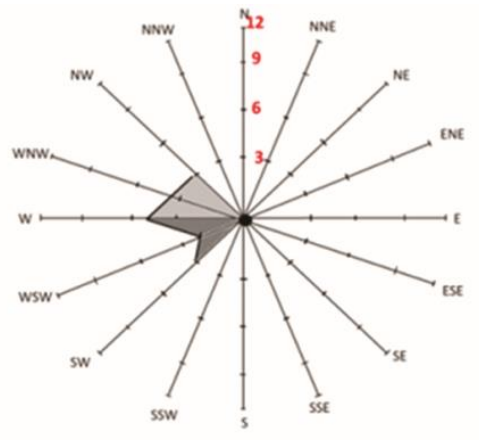

March 2015

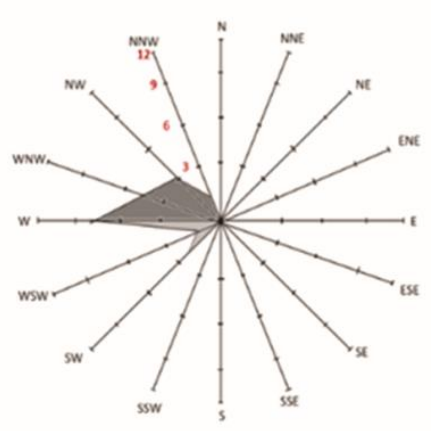

June 2015

Figure 4. Prevailing wind direction in different seasons

\subsection{Sampling and analytical methodology}

Indoor air pollution sampling was done in the selected houses from November 2014-October 2015. $\mathrm{NO}_{2}, \mathrm{SO}_{2}$, $\mathrm{NH}_{3}, \mathrm{CO}, \mathrm{CO}_{2}$ and $\mathrm{PM}_{10} \& \mathrm{PM}_{2.5}$ were measured through 16 hrs. (6:00 a.m.-10:00 p.m.) monitoring. Indoor samples were collected twice every month from each house during the monitoring period. Instruments were set up in the main living area. They were positioned in the centre at a height of $1 \mathrm{~m}$ from the ground at breathing height and at least $1 \mathrm{~m}$ away from any potential source of air pollutant and 3-4 feet away from cooking source (Taneja and Lawrence, 2005). The placing of instruments did not interfere with the normal functioning of the household (Kulshreshtha and Khare, 2011). PM10 and $\mathrm{PM}_{2.5}$ were measured at a flow rate of $1 \mathrm{~m}^{3} / \mathrm{h}$ controlled by critical orifice through an APM 550, Envirotech, India sampler which works on the gravimetric technique. $\mathrm{PM}_{10}$ samples were collected on $47 \mathrm{~mm}$ diameter, $2 \mu \mathrm{m}$ pore size PTFE filters and $\mathrm{PM}_{2.5}$ samples were collected on PTFE Whatman filters with a pore size of $2 \mu \mathrm{m}$, diameter $46.2 \mathrm{~mm}$ with PP ring supported. Filter papers were weighed thrice before and after sampling on a four digit balance (AND HR electronic laboratory balance) with a sensitivity of $0.1 \mathrm{mg}$. Before weighing the samples were equilibrated in a desiccator. Field blank filters were collected to reduce the gravimetric bias due to filter handling during and after sampling. Blank correction was also done to avoid the high background values in the analysis. $\mathrm{H}_{2} \mathrm{~S}$ and $\mathrm{NH}_{3}$ were measured using a YES 205 multigas monitor (YES Environment Technologies Inc. Canada). $\mathrm{SO}_{2}$ and $\mathrm{NO}_{2}$ were measured through a Handy Sampler (Envirotech Instruments Pvt. Ltd., India). CO and $\mathrm{CO}_{2}$ were measured using YES 205 multigas monitor (YES Environment Technologies Inc. Canada) and YES-206 Falcon IAQ monitor (Geo Scientific Ltd., Canada) working on non-dispersive infrared (NDIR) technique.

\subsection{Quality assurance}

Instruments were calibrated before and after the monitoring period or after every seven days. Filter was immerged in 3-4 drops of silicon oil at regular intervals. Daily flow rate calculations (gas meter reading/timer reading) of APM550 were made to make sure that the fluctuations in flow rate were within the range. The sampler is designed to work at a constant flow rate of $16.67 \pm 0.83 \mathrm{~L} / \mathrm{min}$. Filter in the wins impactor were changed after $72 \mathrm{~h}$ of sampling (Chow and Watson, 1998) or when the filter got clogged, as per the operator's judgment.

\subsection{Data entry and analysis}

Data were entered in Microsoft Excel (2010) and exported to SPSS 20.0. Logistic regression and odd ratios were applied to show the association between different variables. Some variables were merged who had small value during the statistical analysis. The mathematical equations were composed using MathType software (version 6.9).

\subsection{Air quality index (AQI)}

Environmental index can predict the overall environmental status. The predictions are done using specific standards. AQI prediction can help general public to understand the quality of air. With the advent of real time AQI monitoring, it represents the overall air quality status in a better way. The index of any specific pollutant is derived mainly from the physical measurement of pollutants like suspended particulate matter, re-suspended particulate matter, $\mathrm{SO}_{2}$ and $\mathrm{NO}_{2}$. In the present study $A Q$ I was calculated for indoor particulate (PM10 and $\mathrm{PM}_{2.5}$ ) concentrations (Inhaber, 1974). The AQI was calculated by three different methods to get an accurate picture. Even low air pollution level causes respiratory and cardiac threats to sensitive groups like elderly, women and children whereas moderate level poses increased menace of respiratory and cardiovascular risks. Heavy pollution conditions exacerbate heart and pulmonary illness and enhanced death rate of children. Severe pollution augments these risks multifold causing dreadful health effects. The different methods employed to calculate AQI are as follows: 
Method I: In this method average concentration of pollutant is calculated with respect to its standard. The average is multiplied by 100 to get the air quality index (Rao and Rao, 2001). AQI was calculated using the method suggested by Tiwari and Ali (Tiwari and Ali, 1987) and followed by Kaushik et al. (Kaushik, Ravindra and Yadav, 2006). The air quality rating was calculated using the following formula

$\mathrm{Q}=(\mathrm{V} / \mathrm{Vs}) 100$

Eq 1. Air quality rating

$\mathrm{Q}=$ Represents quality rating,

$\mathrm{V}=$ Observed value of $\mathrm{PM}_{10}$ and $\mathrm{PM}_{2.5}$

$\mathrm{V}_{\mathrm{s}}=$ the standard value for that pollutant recommended by WHO (2000)

If $Q<100=$ The said parameter is within the prescribed limit

If $Q>100=$ The said parameter exceeds the prescribed limit

All the parameters are given equal importance. The geometric unweighted AQI may be calculated from the quality rating $Q$ by taking their geometric mean-

$$
A Q I=\left[\pi Q^{n_{i=1}}\right]^{(1 / n)} \ldots
$$

This relation is simplified to some extent by taking the common logarithm on both sides.

$$
\begin{aligned}
& \log A Q I=[\log Q+\log Q+\ldots .+\log Q] / n \\
& \log A Q I=\log A Q I=\left[\log Q_{1}+\log Q_{2}+\ldots+\log Q_{n}\right] / n \\
& \log A Q I=\left[\sum_{i=1}^{n} Q_{i}\right] / n \\
& \text { AQI }=\text { Antilog }\left[\sum_{i=1}^{n} Q_{i}\right] / n
\end{aligned}
$$

Method II: The method was developed by the Oak Ridge National Laboratory (ORNL), USA (ORAQI, 1970). The method can be useful for calculation of an overall air quality status at different locations in terms of ranking, with the help of a mathematical equation given below

$$
\mathrm{AQI}=\left[39.02 \sum \frac{X_{i}}{X_{S}}\right]^{0.967}
$$

$X_{i}=$ Value of air quality parameter

$X_{s}=$ Standard prescribed for air quality parameter

The AQI can be categorized under five grades viz. A-E
$A=$ Clean air $(0 \geq A Q I \leq 25)$

$B=$ Light air pollution $(26 \geq A Q I \leq 50)$

$\mathrm{C}=$ Moderate air pollution $(51 \geq \mathrm{AQI} \leq 75)$

$D=$ Heavy air pollution (76 $\geq A Q I \leq 100)$

$E=$ Severe air pollution $(A Q I>100)$

Method III: The third method to calculate AQI was based on combining qualitative and quantitative measures. An index is a single number derived from two or more indicators. In this method individual indicators are calculated, one for each assessment variable. The subindex is calculated as follows

$$
\mathrm{I}_{\mathrm{i}}=\mathrm{W}_{\mathrm{i}} \mathrm{X}_{\mathrm{i}} / \mathrm{X}_{\mathrm{si}}
$$

$W_{i}=$ Weightage of pollutant ' $i$ '

$X_{i}=$ Concentration of pollutant ' $i$ ' $\left(\mu \mathrm{g} \mathrm{m}^{-3}\right)$

$X_{s}=$ Standard limit ' $i$ ' $\left(\mu \mathrm{g} \mathrm{m}^{-3}\right)$

All the air pollutant variable have been given equal importance or given same weightage $\left(W_{i}=1\right)$ and same averaging time as that of the standards. The AQI is calculated as-

$$
I=\sqrt{\frac{1}{N} \sum_{i=1}^{N} I_{i}^{2}}
$$

$\mathrm{N}=$ Number of air quality variables

The descriptors are categorized as-

Acceptable $=0.0 \geq \mathrm{AQI} \leq 0.5$

Unacceptable $=0.51 \geq \mathrm{AQI} \leq 1.0$ to the value near the standard

Alert $=1.01 \geq \mathrm{AQI} \leq 2.0$ value slightly greater than the standard

Significantly harmful $=A Q I \geq 2.01$ to level which is far greater than the standard

\subsection{Health risk assessment}

Inhalation/deposition fluxes for average concentrations of $\mathrm{PM}_{10}, \mathrm{PM}_{2.5}$ were calculated because they exceeded the WHO limits at both rural and urban sites. It has been estimated that the total daily mortality increases by approximately $1 \%$ for every $10 \mu \mathrm{g} \mathrm{m} \mathrm{m}^{-3}$ increase in resuspended particulate concentration (Lippmann, 1998). Inhalation/deposition fluxes were calculated by considering ventilation rates of air $20 \mathrm{~m}^{3}$ day $^{-1}$ for $70 \mathrm{~kg}$ adult and $6 \mathrm{~m}^{3}$ day $^{-1}$ for 2 year old child for human risk characterization (LaGrega, Buckinghan, and Evans, 1994; Khodja et al., 2007).

\section{Results and discussions}

\subsection{Average concentrations of pollutants}

In Lucknow region the year is divided in three seasonssummer, (March-June), rainy (July-October) and winter (November-February). The average concentrations of 
pollutants have been presented in Tables 2 and 3 . In urban houses during winter season the average $\mathrm{PM}_{10}$ concentration was $280 \mathrm{\mu g} \mathrm{m}^{-3}$ as compared to the outdoor concentration which was $211 \mu \mathrm{g} \mathrm{m} \mathrm{m}^{-3}$. The difference in the concentrations may be due to the human occupancy and other indoor sources including the infiltration of road dust. The $\mathrm{PM}_{2.5}$ concentrations varied between 71-200 $\mathrm{\mu g} \mathrm{m}^{-3}$ with an average of $185 \mathrm{\mu g} \mathrm{m}^{-3}$. In rural households the concentration of particulate matter was higher with an average of $315 \mu \mathrm{g} \mathrm{m}^{-3}$ and $210 \mu \mathrm{g} \mathrm{m}^{-3}$ for $\mathrm{PM}_{10}$ and $\mathrm{PM}_{2.5}$ respectively. In winter and rainy seasons the indoor $\mathrm{PM}_{10}$ and $\mathrm{PM}_{2.5}$ values were much higher than the outdoor concentrations, particularly in rural houses.

Rural population still relies on crude fuel for cooking. In rainy season, due to high moisture content in the atmosphere the crude fuel becomes moist and is ignited with a lot of difficulty resulting in a lot of smoke which may contribute to the elevated particulate level. In winter season, ventilation rate is usually low which makes exit of pollutants difficult. Lack of proper ventilation and high humidity can cause increased concentrations indoors (Masih et al., 2017).

Particles with diameters below $10 \mu \mathrm{m}$ ( $\left.\mathrm{PM}_{10}\right)$, and particularly those which are $<2.5 \mu \mathrm{m}$ in diameter $\left(\mathrm{PM}_{2.5}\right)$, can penetrate deeply into the lungs and appear to have the greatest potential for damaging health (Harrison et al., 2002). Diseases like acute upper and lower respiratory infections, COPD, asthma, perinatal mortality, pulmonary tuberculosis, low birth weight (LBW), eye irritation and cataract in women have been linked to cooking using bio-mass in a study conducted in the largest north Indian state Uttar Pradesh (Singh and Jamal, 2011). The size of the particles is strongly related to their ability to cause various health problems. $\mathrm{PM}_{2.5}$ though has a small diameter, but due to the large surface area, the particles are capable of carrying various toxic substances which can pass through the nasal hair and reach the respiratory tract ending with airflow and accumulate there through diffusion thereby causing damage to other parts of the body (Xing et al., 2016).

Among the gaseous pollutants concentrations $\mathrm{CO}$ and $\mathrm{CO}_{2}$ were highest in winter season. In rural houses during winter season the indoor $\mathrm{CO}_{2}$ outweighed the outdoor concentration viz. 652 ppm vs. 366 ppm, though the values were low, still they indicated inadequacy of proper ventilation. $\mathrm{CO}_{2}$ is the common indicator of air quality in built environments (Daisly et al., 2003). Moderate to high levels of carbon dioxide can cause headache and fatigue, and higher concentrations can produce nausea, dizziness, and vomiting. $\mathrm{CO}_{2}$ is evaluated as a common indicator used to assess whether the air exchange rate is sufficient or not (Satish et al., 2012). $\mathrm{NH}_{3}$ had higher concentration in rural houses with the average concentration of 0.018 , 0.065 and $0.341 \mathrm{ppm}$ in summer, rainy and winter seasons respectively. Livestock rearing is a common practice in rural households. Mostly in rainy and winter season people keep them inside the house premise and their excreta may add up to $\mathrm{NH}_{3}$ levels. Gaseous emissions may affect the health of the exposed and the surrounding environment. Long term indoor air quality assessment in such households may help in designing mitigation strategies and coming up with control policies for the emitting sources (Samer et al., 2011), as well as the health and well-being of the animals. $\mathrm{NH}_{3}$ concentrations may also occur due to low temperature, reduced volatility and high relative humidity (Fukae and Takenaka, 2018). $\mathrm{NH}_{3}$ may also react with $\mathrm{SO}_{2}$ and $\mathrm{NO}_{x}$ in the atmosphere to form particulate matter with a diameter of 2.5 micron.

Usually pollutants were in higher concentration in winter season followed by summer and rainy. In winters the climatic conditions are more or less calm and there is a greater atmospheric stability and the dispersion and dilution of pollutants is restricted owing to temperature inversion and low mixing heights (Masih et al., 2016). In summer season there are occurrences of frequent dust storms, known as andhi, leading to unstable atmospheric conditions (Singla et al., 2012). In rainy season the wash out effect dominates. $\mathrm{SO} 2$ and $\mathrm{NO} 2$ were within the permissible limits during the monitoring period. They are the usual by products associated with the combustion of biofuels (Rios, Vedal and Pare, 2004). Exacerbated disease outcomes have been associated with the inhalation of the combustible products (Kreuter and Hoylaerts, 2004). In urban environment the concentrations of indoor $\mathrm{SO}_{2}$ and $\mathrm{NO}_{2}$ were highest. The probable reason accounting for the variation may be the use of heavy diesel generators due to frequent power cuts (Kaushik et al., 2006). $\mathrm{H}_{2} \mathrm{~S}$ concentrations were very low in each season, yet it has been observed that the gas can be smelled even at $0.01 \mathrm{ppm}$. In rural houses during rainy season the concentration of $\mathrm{H}_{2} \mathrm{~S}$ reached to $0.2 \mathrm{ppm}$. The poor sanitary condition in rural houses may be responsible for that.

Livestock housing is a major source of harmful gases viz. $\mathrm{CH}_{4}, \mathrm{NH}_{3}, \mathrm{CO}_{2}, \mathrm{H}_{2} \mathrm{~S}$ and $\mathrm{N}_{2} \mathrm{O}$ (Moumen et al., 2016). It is considered as a broad-spectrum poison which can affect human systems particularly the nervous system. Long period of exposure can lead to fatigue, headache, irritability and dizziness etc. 
Table 2. Season wise average concentrations of pollutants in urban houses from November14-October 15

\begin{tabular}{|c|c|c|c|c|c|}
\hline Pollutant & Season & Avg. conc. & Max. & Min. & Standard Dev. \\
\hline \multirow[t]{6}{*}{$\mathrm{CO}_{2}(\mathrm{ppm})$} & \multirow[t]{2}{*}{ Summer } & I-389.75 & \multirow[t]{2}{*}{412} & \multirow[t]{2}{*}{372} & \multirow[t]{2}{*}{17.93} \\
\hline & & $0-416$ & & & \\
\hline & \multirow[t]{2}{*}{ Rainy } & $1-370$ & \multirow[t]{2}{*}{382} & \multirow[t]{2}{*}{358} & \multirow[t]{2}{*}{11.77} \\
\hline & & $0-394.75$ & & & \\
\hline & \multirow[t]{2}{*}{ Winter } & $\mathrm{I}-452$ & \multirow[t]{2}{*}{552} & \multirow[t]{2}{*}{406} & \multirow[t]{2}{*}{67.5} \\
\hline & & $0-339.75$ & & & \\
\hline \multirow[t]{6}{*}{$\mathrm{CO}$ (ppm) } & \multirow[t]{2}{*}{ Summer } & $\mathrm{I}-0.125$ & \multirow[t]{2}{*}{0.2} & \multirow[t]{2}{*}{0.1} & \multirow[t]{2}{*}{0.05} \\
\hline & & $0-0.3725$ & & & \\
\hline & \multirow[t]{2}{*}{ Rainy } & $1-0.05$ & \multirow[t]{2}{*}{0.1} & \multirow[t]{2}{*}{$\mathrm{BDL}$} & \multirow[t]{2}{*}{0.057} \\
\hline & & $0-1.000$ & & & \\
\hline & Winter & $\mathrm{I}-0.245$ & 0.5 & 0.09 & 0.194 \\
\hline & & $0-1.6$ & & & \\
\hline $\mathrm{NH}_{3}(\mathrm{ppm})$ & Summer & I-0.0285 & 0.05 & 0.015 & 0.015 \\
\hline & & $0-0.075$ & & & \\
\hline & Rainy & I- 0.03 & 0.05 & 0.02 & 0.014 \\
\hline & & O- 0.0275 & & & \\
\hline & Winter & I- 0.01775 & 0.028 & 0.01 & 0.008 \\
\hline & & $0-0.079$ & & & \\
\hline $\mathrm{SO}_{2}(\mathrm{ppm})$ & Summer & I- 0.0122 & 0.019 & 0.009 & 0.004 \\
\hline & & 00.0295 & & & \\
\hline & Rainy & $\mathrm{I}-0.02725$ & 0.05 & 0.019 & 0.0151 \\
\hline & & $0-0.0235$ & & & \\
\hline & Winter & $1-0.0302$ & 0.039 & 0.951 & 0.0065 \\
\hline & & $0-0.0300$ & & & \\
\hline $\mathrm{NO}_{2}(\mathrm{ppm})$ & Summer & $\mathrm{I}-0.0475$ & 0.08 & 0.0838 & 0.0320 \\
\hline & & $0-0.0277$ & & & \\
\hline & Rainy & $\mathrm{I}-0.045$ & 0.09 & 0.01 & 0.0341 \\
\hline & & $0-0.089$ & & & \\
\hline & Winter & I-0.0165 & 0.021 & 0.01 & 0.004 \\
\hline & & $0-0.0225$ & & & \\
\hline $\mathrm{H}_{2} \mathrm{~S}$ (ppm) & Summer & I- 0.0024 & 0.001 & $\mathrm{BDL}$ & 0.005 \\
\hline & & O- 0.1015 & & & \\
\hline & Rainy & $\mathrm{I}-0.0125$ & 0.003 & $\mathrm{BDL}$ & 0.01 \\
\hline & & O- 0.0425 & & & \\
\hline & Winter & I- BDL & $\mathrm{BDL}$ & $\mathrm{BDL}$ & 0.0 \\
\hline & & O- 0.03025 & & & \\
\hline $\mathrm{PM}_{10}\left(\mu \mathrm{g} \mathrm{m}^{-3}\right)$ & Summer & $\mathrm{I}-215$ & 265 & 152 & 18.57 \\
\hline & & $0-237$ & & & \\
\hline & Rainy & $\mathrm{I}-145$ & 158 & 98 & 26.79 \\
\hline & & $0-93$ & & & \\
\hline & Winter & $\mathrm{I}-280$ & 315 & 159 & 40.352 \\
\hline & & $0-211$ & & & \\
\hline $\mathrm{PM}_{2.5}\left(\mu \mathrm{g} \mathrm{m}^{-3}\right)$ & Summer & $\mathrm{I}-160$ & 176 & 89 & 28.894 \\
\hline & & $0-106$ & & & \\
\hline & Rainy & $\mathrm{I}-84$ & 101 & 53 & 10.954 \\
\hline & & $0-65$ & & & \\
\hline & Winter & $\mathrm{I}-185$ & 200 & 71 & 25.408 \\
\hline & & $0-90$ & & & \\
\hline
\end{tabular}

Note: Average concentration for a normal 16 hour work day (6:00 am-10:00 pm.) covering major indoor activities, BDL =Below detection level 
Table 3 Season wise average concentrations of pollutants in rural houses from November14-October 15

\begin{tabular}{|c|c|c|c|c|c|}
\hline Pollutant & Season & Avg. conc. & Max. & Min. & Standard Dev. \\
\hline \multirow[t]{6}{*}{$\mathrm{CO}_{2}(\mathrm{ppm})$} & \multirow[t]{2}{*}{ Summer } & I-385.5 & \multirow[t]{2}{*}{469} & \multirow[t]{2}{*}{352} & \multirow[t]{2}{*}{55.848} \\
\hline & & $0-374.7$ & & & \\
\hline & \multirow[t]{2}{*}{ Rainy } & I-527.25 & \multirow[t]{2}{*}{626} & \multirow[t]{2}{*}{421} & \multirow[t]{2}{*}{86.865} \\
\hline & & $0-375.25$ & & & \\
\hline & \multirow[t]{2}{*}{ Winter } & I-652.5 & \multirow[t]{2}{*}{818} & \multirow[t]{2}{*}{478} & \multirow[t]{2}{*}{140.277} \\
\hline & & $0-366.5$ & & & \\
\hline \multirow[t]{6}{*}{$\mathrm{CO}(\mathrm{ppm})$} & \multirow[t]{2}{*}{ Summer } & $\mathrm{I}-0.038$ & \multirow[t]{2}{*}{0.3} & \multirow[t]{2}{*}{0.0} & \multirow[t]{2}{*}{0.15} \\
\hline & & O-BDL & & & \\
\hline & \multirow[t]{2}{*}{ Rainy } & $\mathrm{I}-0.75$ & \multirow[t]{2}{*}{1.7} & \multirow[t]{2}{*}{0.2} & \multirow[t]{2}{*}{0.714} \\
\hline & & $0-0.525$ & & & \\
\hline & Winter & $\mathrm{I}-1.3$ & 1.9 & 0.3 & 0.697 \\
\hline & & $0-0.15$ & & & \\
\hline $\mathrm{NH}_{3}(\mathrm{ppm})$ & Summer & $1-0.038$ & 0.096 & 0.012 & 0.039 \\
\hline & & $0-0.0257$ & & & \\
\hline & Rainy & $\mathrm{I}-0.050$ & 0.084 & 0.029 & 0.025 \\
\hline & & $0-0.5250$ & & & \\
\hline & Winter & $1-0.645$ & 0.09 & 0.03 & 0.025 \\
\hline & & $0-0.0245$ & & & \\
\hline $\mathrm{SO}_{2}(\mathrm{ppm})$ & Summer & I- 0.0255 & 0.042 & 0.017 & 0.011 \\
\hline & & O- 0.0272 & & & \\
\hline & Rainy & $\mathrm{I}-0.325$ & 0.063 & 0.009 & 0.023 \\
\hline & & $0-0.0262$ & & & \\
\hline & Winter & $\mathrm{I}-0.023$ & 0.043 & 0.009 & 0.016 \\
\hline & & $0-0.0072$ & & & \\
\hline $\mathrm{NO}_{2}(\mathrm{ppm})$ & Summer & $1-0.027$ & 0.039 & 0.004 & 0.014 \\
\hline & & O- 0.0675 & & & \\
\hline & Rainy & $\mathrm{I}-0.0287$ & 0.037 & 0.021 & 0.006 \\
\hline & & $0-0.0882$ & & & \\
\hline & Winter & $1-0.0152$ & 0.02 & 0.011 & 0.004 \\
\hline & & $0-0.0060$ & & & \\
\hline $\mathrm{H}_{2} \mathrm{~S}$ (ppm) & Summer & $1-0.0025$ & .001 & $\mathrm{BDL}$ & 0.005 \\
\hline & & O- BDL & & & \\
\hline & Rainy & $1-0.2$ & 0.2 & 0.2 & 0.2 \\
\hline & & O-BDL & & & \\
\hline & Winter & $\mathrm{I}-0.075$ & 0.2 & $\mathrm{BDL}$ & 0.09 \\
\hline & & $0-0.034$ & & & \\
\hline $\mathrm{PM}_{10}\left(\mu \mathrm{g} \mathrm{m}^{-3}\right)$ & Summer & I- 87 & 94 & 54 & 62.487 \\
\hline & & $0-103.25$ & & & \\
\hline & Rainy & $\mathrm{I}-264$ & 280 & 137 & 89.914 \\
\hline & & $0-112.75$ & & & \\
\hline & Winter & $\mathrm{I}-315$ & 342 & 194 & 46.65 \\
\hline & & $0-63.5$ & & & \\
\hline $\mathrm{PM}_{2.5}\left(\mu \mathrm{g} \mathrm{m}^{-3}\right)$ & Summer & I- 51 & 71 & 89 & 19.120 \\
\hline & & O- 47.5 & & & \\
\hline & Rainy & I-143 & 145 & 66 & 35.688 \\
\hline & & $0-22$ & & & \\
\hline & Winter & $\mathrm{I}-210$ & 225 & 81 & 44.274 \\
\hline & & $0-42.25$ & & & \\
\hline
\end{tabular}




\subsection{Indoor/outdoor ratio of the pollutants}

Indoor/outdoor ratio was calculated for each pollutant in all the three seasons. The $1 / 0$ ratio for $\mathrm{PM}_{2.5}$ was 2.0 during winter season in urban households. The $1 / 0$ ratio for $\mathrm{PM}_{10}$ was found to be 1.5 in rainy season. Among the gaseous pollutant $\mathrm{I} / \mathrm{O}$ ratio for $\mathrm{NO}_{2}$ was 1.7 in summer season and for $\mathrm{CO}_{2}$ it was 1.3 in winter season. In rural households during winter season, the $\mathrm{I} / \mathrm{O}$ ratios for $\mathrm{PM}_{10}$ and $\mathrm{PM}_{2.5}$ exceeded 4.0 showing significantly higher indoor levels than outdoors. The value suggested the presence of potent indoor sources. I/O ratio for $\mathrm{NH}_{3}$ was 13.9 in winter season.

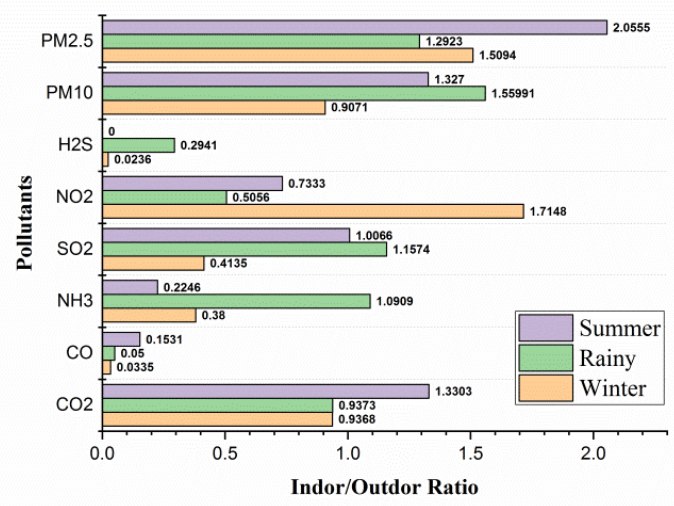

Figure 5. Indoor/Outdoor ratios for various pollutants in urban environment

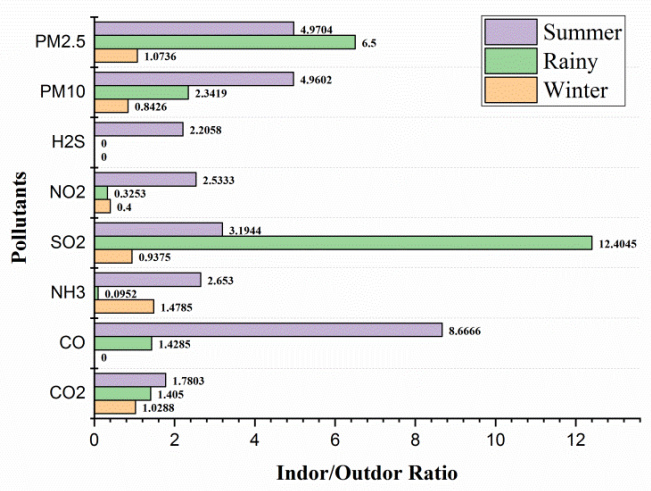

Figure 6. Indoor/Outdoor ratios for various pollutants in rural environment

\subsection{Questionnaire survey results}

The questionnaire was used to collect observational data including information on household conditions, ventilation conditions, number of occupants, daily activity pattern and health status of the occupants. The questionnaire included questions regarding the age of the house, building material, mode of ventilation, family members (numbers of adults, children \& sick), household activities, presence of smokers/non-smokers, oil/fuels used for cooking and the material used during prayer (e.g. incense). The residents were also asked to mention health complaints, illness and any other symptoms. House characteristics are given in Table 4. Majority of rural houses (96\%) used traditional earthen chulhas (stoves) for cooking and heating. (Figure 4). A lot of smoke is produced by the unvented stove while burning wood, dung and crop waste in it which can cause breathlessness, discomfort and headache. Type of stove used for cooking and heating has been found to influence indoor environment (Baek, Kim and Perry, 1997). Rural inhabitants mainly relied on wood, coal and kerosene as energy sources. $65 \%$ sampled rural households mainly relied on wood, coal and cow dung to meet energy requirements. Electricity consumption was particularly low in rural houses owing to low educational and socioeconomic background. Ventilation was mainly natural in rural houses. Livestock rearing was a common practice in rural environment. Educational profile of rural dwellers was fairly low. In urban houses the indoor air quality was largely affected by the vehicular emission and its infiltration in addition to some indoor sources and practices. Pollutants such as aldehydes, volatile and semi volatile organic compounds are produced from polishing materials, paints and cosmetics etc. Biological pollutants like dust mites, molds and pollens are produced in mattresses, carpets and humidifiers which contaminate the indoor air substantially (Zhang and Smith, 2003). These pollutants can cause irritation of the mucous lining of the respiratory tract reaching from the nose to the bronchi (Mohapatra, Das and Samantaray, 2018). It has been observed that indoor sources and practices such as ventilation equipment, furniture and human factors and activities (number of pupils in the classroom, class durations, breaks between classes, etc.) also greatly influence the indoor air quality.

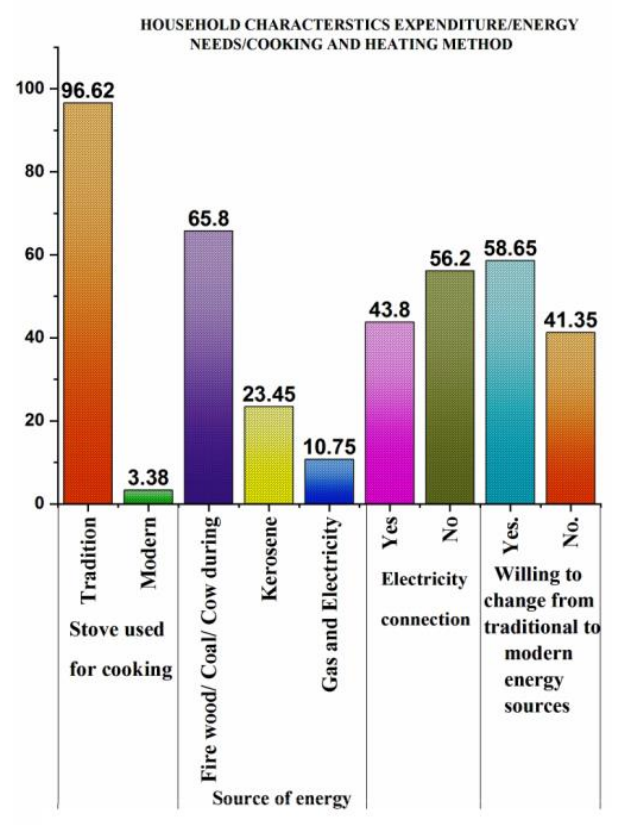

Figure 7. Energy usage pattern in rural houses 
Table 4. Description of sampling houses in urban and rural environment

\begin{tabular}{|c|c|c|c|c|c|c|}
\hline Microenvironment & House age and height & Living room area & Number of inhabitants & Ventilation & Type of fuel & Heating source \\
\hline Alambagh & 20 years $\& 16 \mathrm{ft}$. & $12 \mathrm{~m}^{2}$ & 7 & $\begin{array}{c}\text { Through windows and } \\
\text { exhaust fans }\end{array}$ & LPG & Electric heaters \\
\hline Munshipulia & 10 years and $14.5 \mathrm{ft}$. & $14 \mathrm{~m}^{2}$ & 5 & $\begin{array}{c}\text { Through windows and } \\
\text { exhaust fans }\end{array}$ & LPG and electric heaters & Electric heaters \\
\hline Chowk & More than 50 years \& $20 \mathrm{ft}$. & $16 \mathrm{~m}^{2}$ & 9 & $\begin{array}{l}\text { Cross ventilation mainly } \\
\text { through large windows }\end{array}$ & LPG and kerosene & $\begin{array}{l}\text { Electric heaters and } \\
\text { earthen hearths using } \\
\text { wood }\end{array}$ \\
\hline Balaganj & 8 years $\& 15 \mathrm{ft}$. & $20 \mathrm{~m}^{2}$ & 5 & Mainly through exhaust fans & LPG & Electric heaters \\
\hline Mahanagar & 12 years and $14 \mathrm{ft}$. & $24 \mathrm{~m}^{2}$ & 4 & $\begin{array}{l}\text { Mainly through exhaust fans } \\
\text { and chimneys }\end{array}$ & LPG & $\begin{array}{c}\text { Electric heaters and } \\
\text { blowers }\end{array}$ \\
\hline Gudamba & 12 years $\& 13 \mathrm{ft}$. & $3 \mathrm{~m}^{2}$ & 7 & $\begin{array}{l}\text { Natural ventilation. Mainly } \\
\text { through windows }\end{array}$ & Wood, cow dung, coal, kerosene & Earthen stoves \\
\hline Malihabad & More than 30 years \& $14 \mathrm{ft}$. & $7 \mathrm{~m}^{2}$ & 8 & $\begin{array}{c}\text { Natural ventilation. Mainly } \\
\text { through windows }\end{array}$ & Wood, cow dung, coal, kerosene & Earthen stoves \\
\hline Bijnaur & 13 years $\& 10 \mathrm{ft}$. & $4 \mathrm{~m}^{2}$ & 6 & $\begin{array}{l}\text { Natural ventilation. Mainly } \\
\text { through windows }\end{array}$ & Wood, cow dung, coal, kerosene & Earthen stoves \\
\hline Kakori & 25 years $\& 13 \mathrm{ft}$. & $4 m^{2}$ & 6 & $\begin{array}{l}\text { Natural ventilation Mainly } \\
\text { through windows }\end{array}$ & Wood, cow dung, coal, kerosene & Earthen stoves \\
\hline Arjunpur & 22 years and $12 \mathrm{ft}$. & $12 \mathrm{~m}^{2}$ & 8 & $\begin{array}{l}\text { Natural ventilation. Mainly } \\
\text { through windows }\end{array}$ & Wood, cow dung, coal, kerosene & Earthen stoves \\
\hline
\end{tabular}




\subsection{Air quality index}

The AQI was calculated for particulate concentrations as they exceeded the WHO 2000 standards. For accuracy and validation, the index was calculated by three different methods. Particulate matter enters deep into the respiratory tract and reaching the lungs. AQI values were highest in winter season and particularly poor in rural houses viz. 716.1, 457.0, 7.427 as calculated by the three methods. The calculated AQI values are presented in Table 5. In urban houses during winter season the AQI values were highest. The highest $A Q I$ values in urban sites were obtained from Chowk and Alambagh areas which were categorized as densely populated and roadside microenvironments respectively. Meteorological factors like high relative humidity and low temperature may be responsible for the exacerbation of pollution during winters. Lower wind speed and mixing height do not allow wind to disperse quickly leading to higher concentration of pollutants on the surface. Indoor activity pattern, human occupancy and tobacco smoke have also been found to influence indoor air quality. Inadequate ventilation can increase indoor pollutant levels by not bringing enough outdoor air to dilute emissions from indoor sources (Mukkannawar, Kumar and Ojha, 2014). These factors are responsible for marked difference between outdoor and indoor concentrations and accountable for various health hazards.

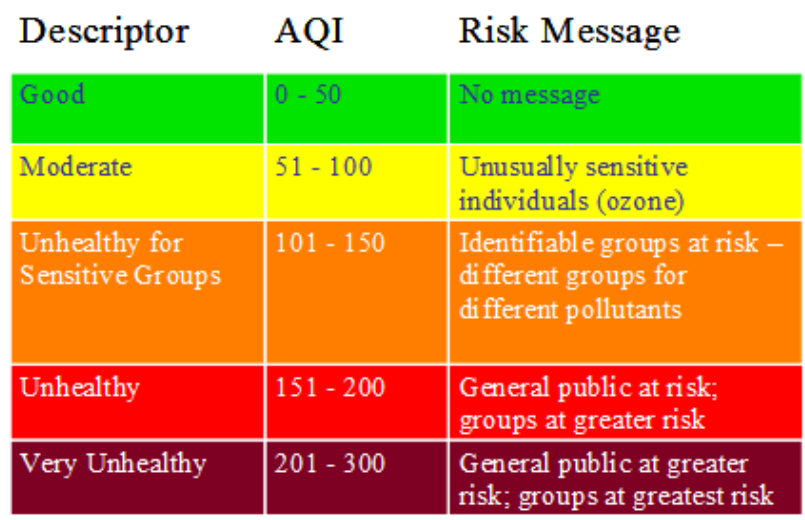

Figure 8. AQI values and associated Risk Message

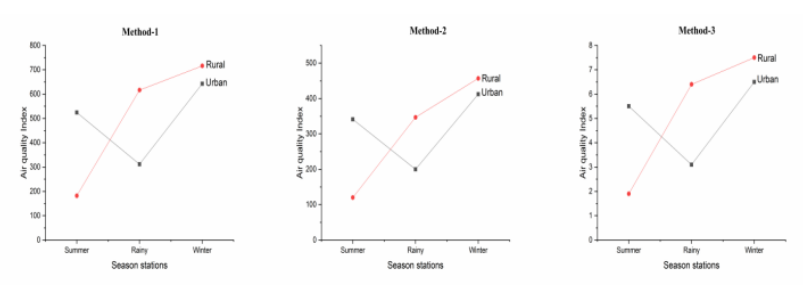

Figure 9. AQI comparison

Table 5. AQI values for urban and rural environment

\begin{tabular}{ccccccc}
\hline \multirow{2}{*}{ Method } & \multicolumn{2}{c}{ Summer } & \multicolumn{2}{c}{ Rainy } & \multicolumn{2}{c}{ Winter } \\
\cline { 2 - 7 } & Urban & Rural & Urban & Rural & Urban & Rural \\
\hline 1 & 524.20 & 181.9 & 311.8 & 616.5 & 642.6 & 716.1 \\
\hline 2 & 341.1 & 120 & 199.9 & 346.7 & 412.1 & 457.0 \\
\hline 3 & 5.5 & 1.9 & 3.1 & 6.4 & 6.5 & 7.5 \\
\hline
\end{tabular}

\subsection{Inhalation rate calculation of particulate matter}

The health risk assessment is a tool used for pollution management. The health risk assessment is done by combining the results of studies which reflect the health effects of the pollutant with those which estimate the level of people's exposures at different distances from the source of the pollutant. The estimates provided by these risk assessments help scientists evaluate the risks associated with emissions of toxic air pollutants. Using risk estimates and other factors, the government can set regulatory standards to reduce people's exposures to toxic air pollutants and reduce the risk of health problems. Inhalation/deposition fluxes of average concentration of particulate matter were calculated in each season by considering breathing rates of air $20 \mathrm{~m}^{3}$ day $^{-1}$ for $70 \mathrm{~kg}$ adult and $6 \mathrm{~m}^{3}$ day $^{-1}$ for 2 year old child for human risk characterization. People living in $45 \%$ districts of India are exposed to $\mathrm{PM}_{2.5}$ concentrations beyond $40 \mu \mathrm{g} \mathrm{m} \mathrm{m}^{-3}$ (Chowdhury and Dey, 2016). According to a recent Global air 2017 report, exposure to $\mathrm{PM}_{2.5}$ is a leading environmental risk factor, accounting for about 4.2 million deaths (State of Global Air report, 2017). The analysis revealed that inhalation of particulate matter was highest in winter season. In rural houses the calculated inhalation rates for an adult were 503.22 and $345.45 \mu$ day $^{-1}$ with respect to $\mathrm{PM}_{10}$ and $\mathrm{PM}_{2.5}$, whereas for a child the inhalation rates were 345.49 and $102.3 \mu \mathrm{g} \mathrm{day}{ }^{-1}$ respectively. Particulate emission depends upon a plethora of factors. Long term exposure to particulate matter is associated with reduced average life expectancy from 8.5 to 20 months and increase in the long term risk of cardiopulmonary mortality by $6-13 \%$ per $\mu \mathrm{g} \mathrm{m} \mathrm{m}^{-3}$ (Krewsk et al., 2009).

\subsection{Assessment of health status}

A questionnaire survey was done with 971 respiratory patients and the symptoms reported by them were sorted season wise. Dry throat was a prominent symptom reported in summer season by the urban respondents whereas skin irritation was prevalent in rainy season, especially among rural dwellers. In winter season the commonly reported symptoms were congestion and sneezing. The prevalence of respiratory illnesses and symptoms were considerably higher among rural dwellers. Exposure to solid fuel smoke is consistently associated with COPD and chronic bronchitis in developing countries (Kurmi et al., 2010). Over exposure to smoke originating from unvented stoves may result in eye infections and other respiratory issues as shown by the past studies. Dung cakes were a common sight in rural households. Dung cake particulate suspensions have been found to deplete antioxidants like ascorbate, urate and glutathione from a synthetic model of human respiratory tract lining fluid (Mudway and Kelly, 1998; Mudwayet al., 2004). Per unit heat emissions of $\mathrm{CO}$ and total suspended particles from dung cakes and crop residues are 2-3 times higher than from fuel wood (Veena, Chandra and Ahuja, 2005). Climatic conditions and indoor human occupancy can also lead to imbalance and undesired changes in the indoor air quality leading to discomfort of the occupants 
like suffocation, headache, drowsiness and lack of concentration. A simple linear regression analysis was applied to establish a relationship between the health symptoms and crude fuel usage. A correlation $\left(R^{2}=0.7114\right)$ was obtained between the two parameters in rural environment. A similar correlation was found in a previous study between household air pollution and neonatal mortality being conducted in 284 districts of nine states in India (Neogi et al., 2015). Because of the presence of several confounders like quality of cooking oil, ventilation, smoking, incense burning, animal excreta, building material like vinyl floor, particle board, sealant, gypsum board, carpet, paint and varnish etc. interpretation of the results should be taken as suggestive rather than definitive. Self-reported symptoms were obtained to assess the health status. Factors like educational profile, life style, socio-economic status and nutritional status also may have significant influence on the extent of exposure to indoor air pollution.

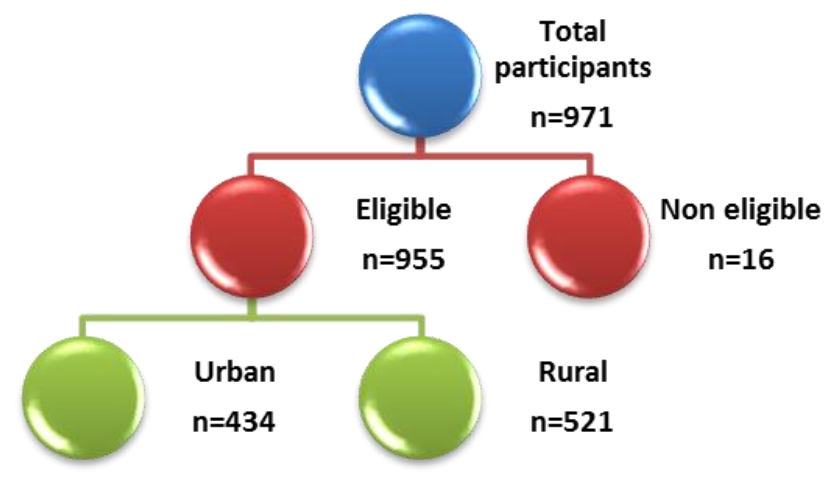

Figure 10. Flow diagram showing distribution of study participants

Table 6. Distribution of symptoms

\begin{tabular}{|c|c|c|c|c|c|}
\hline \multicolumn{2}{|c|}{$\begin{array}{l}\text { Number of } \\
\text { complaints in } \\
\text { summer season }\end{array}$} & \multicolumn{2}{|c|}{$\begin{array}{l}\text { Number of } \\
\text { complaints in } \\
\text { rainy season }\end{array}$} & \multicolumn{2}{|c|}{$\begin{array}{c}\text { Number of } \\
\text { complaints in winter } \\
\text { season }\end{array}$} \\
\hline 67 & Dry throat & 41 & $\begin{array}{c}\text { Skin } \\
\text { irritation }\end{array}$ & 90 & $\begin{array}{l}\text { Sinus and } \\
\text { congestion }\end{array}$ \\
\hline 48 & $\begin{array}{c}\text { Shortness of } \\
\text { breath }\end{array}$ & 36 & $\begin{array}{c}\text { Eye } \\
\text { irritation }\end{array}$ & 54 & Sneezing \\
\hline 29 & Sneezing & 29 & Cough & 32 & Headache \\
\hline
\end{tabular}

3.7. Elevation in particulate concentration during cooking period in rural households

To assess the difference in concentration of particulate matter between cooking and non-cooking period, $24 \mathrm{~h}$ monitoring was done in one rural house. The meals were cooked between 6:00 a.m.-6:00 p.m, so the time was defined as cooking period. 7:00 p.m.-11:00 p.m. was defined as the non-cooking period. On an average two hours were taken to cook one meal. Average particulate concentration between non-cooking and cooking hours showed considerable difference. When cooking was in progress, the concentration of $\mathrm{PM}_{10}$ reached to $286 \mathrm{\mu g} \mathrm{m}^{-3}$ as compared to $104 \mathrm{\mu g} \mathrm{m}^{-3}$ during the non-cooking period.

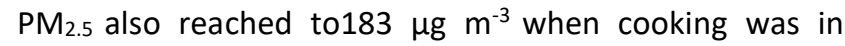
progress. Even after cooking was completed, smoke from the earthen stoves kept evolving thereby making the indoor conditions highly unfavorable. The findings were supported by similar observations in another study which revealed that the use of biomass for cooking caused drastic increase in particulate concentration (Balakrishnan et al., 2002). Women are primary sufferers because of their pivotal role in cooking (Behera, Dash and Malik, 1988). The variation in particulate concentration during cooking in one of the rural sites in Kenya suggested that mean $\mathrm{PM}_{10}$ concentration near the fire reached upto $1,250 \mathrm{\mu g} \mathrm{m}^{-3}$ (Ezzati, Saleh and Kammen, 2000).

\section{Conclusion}

The present study was attempted to assess the indoor air quality by measuring some of the major air pollutants viz. $\mathrm{CO}, \mathrm{CO}_{2}, \mathrm{NO}_{2}, \mathrm{SO}_{2}, \mathrm{NH}_{3}, \mathrm{H}_{2} \mathrm{~S}, \mathrm{PM}_{10}$ and $\mathrm{PM}_{2.5}$ in urban and rural houses of Lucknow region. Indoor air pollution is still a less explored fact in Indian households, especially in rural areas. The study highlighted the indoor household conditions in a typical urban and rural household and the choices, availability and adequacy of energy resources used by the dwellers along with the health effects associated with inefficient sources of energy.

Many indoor factors were identified which may affect the indoor air quality potentially. The air quality was particularly poor in rural houses during winter season. $\mathrm{PM}_{10}$ and $\mathrm{PM}_{2.5}$ reached upto 342 and $225 \mu \mathrm{g} \mathrm{m} \mathrm{m}^{-3}$ respectively whereas among the gaseous concentration, $\mathrm{CO}_{2}$ and $\mathrm{CO}$ reached maximal to 818 and $1.9 \mathrm{ppm}$. The common offender in rural houses was the combustion of crude fuel. The household conditions were also unsatisfactory with high level of dampness, leaky roofs and poor hygiene. In urban houses indoor quality was largely affected by permeation of outdoor pollutants due to heavy automobile traffic and construction activities. Skin irritation, dry throat, cough, sneezing and sinus were some of the common symptoms reported by the people. There were other symptoms reported as well for which the available data is insufficient and inconsistent. The study provided strong evidence of indoor air pollution in considered households, still there is scope to further strengthen the correlation between the exposure of indoor pollutants with pulmonary and cardiovascular health symptoms.

In rural areas there is an urgent need to change pattern of fuel as the study revealed majority of households relied on biomass based fuel. The traditional cooking chulhas must be replaced or modified to more efficient ones. As the educational profile of the rural subjects was quite low, it is therefore recommended to up the ante of better education facilities and to aware the population about the alternative energy sources which are more cleaner. Further studies are also needed to establish a correlation between indoor air pollution and health problems in a dose-dependent manner.

\section{Conflicts of Interest}

The authors declare they have no competing interests 


\section{Acknowledgements}

The authors acknowledge Dr. (Mrs.) V. Prakash, Principal, Isabella Thoburn College, Lucknow for her support and providing necessary facilities for conducting the research.

\section{References}

Abdelmajid M., Azizi G., Ben C. and Mourad B. (2016), The effects of livestock methane emission on the global warming: A review, International Journal of Global Warming, 9(2), 229-253.

Baek S.O., Kim Y.S. and Perry R. (1997), Indoor air quality in homes, offices and restaurants in Korean urban areas indoor/outdoor relationships, Atmospheric Environment, 31, 529-544.

Balakrishnan K., Parikh J., Sankar S., Parikh J., Padmavathi R., Srividya K., Venugopal V., Prasad S. and Pandey V.L. (2002), Daily average exposures to respirable particulate matter from combustion of biomass fuels in rural households of southern India, Environmental Health Perspectives, 110, 1069-1075.

Balakrishnan K., Sambandam S., Ramaswamy P., Ghish S., Venkatesan V., Thangavel G., Mukhopadhyay K., Johnson P., Paul S., Puttaswamy N., Dhaliwal R.S. and Shukla D.K. (2015), Establishing integrated rural-urban cohorts to assess air pollution-related health effects in pregnant women, children and adults in Southern India: an overview of objectives, design and methods in the Tamil Nadu Air Pollution and Health Effects (TAPHE) study, BMJ Open, 5(6).

Banerjee T. and Srivastava R.K. (2011), Evaluation of environmental impacts of Integrated Industrial EstatePantnagar through application of air and water quality indices, Environmental Monitoring and Assessment, 172, 547-560.

Behera D., Dash S. and Malik S. (1988), Blood carboxyhaemoglobin levels following acute exposure to smoke of biomass fuel, Indian Journal of Medical Research, 88, 522 .

Chow J.C. and Watson J.G. (1998), Guidelines on speciated particulate monitoring, USEPA office of air quality planning and standards, Res Training Park, p. 291.

Chowdhury S. and Dey S. (2016), Cause-specific premature death from ambient PM2.5 exposure in India: Estimate adjusted for baseline mortality, Environment International, 91, 283-290.

Daisly J.M., Angell W.J. and Apte M.G. (2013), Indoor air quality, ventilation and heath symptoms in schools: an analysis of existing information, Indoor Air, 13, 1, 53-64.

Ezzati M., Saleh H. and Kammen D.M. (2000), The contributions of emissions and spatial microenvironments to exposure to indoor air pollution from biomass combustion in Kenya, Environmental Health Perspectives, 108, 833-839.

Fukae K. and Takenaka N. (2018), Application of Passive Sampler for Ammonia Gas in Soil, Water, Air, \& Soil Pollution, 229, 145. https://doi.org/10.1007/s11270-0183797-y.

Garaga R. and Kota S.H. (2018), Characterization of $\mathrm{PM}_{10}$ and Impact on Human Health During the Annual Festival of Lights (Diwali), Journal of Health and Pollution, 8(20), 181-206.

Harrison R., Thornton C., Lawrence R., Mark D., Kinnerseley R. and Ayres J. (2002), Personal exposure monitoring of particulate matter, nitrogen dioxide, and carbon monoxide, including susceptible groups, Occupational and
Environmental Medicine, 59(10), 671-679. doi:10.1136/oem. 59.10.671.

http://www.cpcb.nic.in/RealTimeAirQualityData.php

Inhaber H. (1974), A set of suggested air quality indices for Canada. Atmospheric Environment, 9(3), 353-364.

Kankaria A., Nongkynrih B. and Gupta S.K. (2014), Indoor air pollution in India: Implications on health and its control, Indian Journal of Community Medicine, 39, 203-207.

Kaushik P., Ravindra K., Yadav K., Mehta S. and Haritash A.K. (2006), Assessment of ambient air quality in urban centres of Haryana (India) in relation to different anthropogenic activities and health risks, Environmental Monitoring and Assessment, 122, 27-40. DOI: 10.1007/s10661-005-9161-x_c Springer 2006.

Khodja H.A., Belaala A., Debbih W., Habbas B. and Boumagoura N. (2007), DOI 10.1007/s10661-007-9792-1.

Kreuter R.O. and Hoylaerts H.M. (2004), Particulate and gaseous emission form wood burning, Environmental Science \& Technology, 16(10), 639-645.

Krewski D., Jerrett M., Burnett R.T., Ma R., Hughes E., Shi Y., Turner M.C., Pope C.A. 3rd., Thurston G., Calle E.E., Thun M.J., Beckerman B., DeLuca P., Finkelstein N., Ito K., Moore D.K., Newbold K.B., Ramsay T., Ross Z., Shin H. and Tempalski B. (2009), Extended Follow-Up and Spatial Analysis of the American Cancer Society Study Linking Particulate Air Pollution and Mortality, HEI Research Report 140, Health Effects Institute, Boston, MA.

Kulshreshtha P. and Khare M. (2011), Indoor exploratory analysis of gaseous pollutants and respirable particulate matter at residential homes of Delhi, Atmospheric Pollution Research, 2, 337-350.

Kurmi O.P., Simkhada S., Simkhada P., Smith W.C. and Ayres J.G. (2010), COPD and chronic bronchitis risk of indoor air pollution from solid fuel:a systematic review and metaanalysis, Thorax, 65(3), 221-228. DOI:10.1136/thx.2009.124 644.

LaGrega M.D., Buckinghan P.L. and Evans J.C. (1994), Apendix B: Toxicological data. In Hazardous waste management, McGraw-Hill, Singapore.

Lawrence A.J., Masih A. and Taneja A. (2005), Indoor/outdoor relationships of carbon monoxide and oxides of nitrogen in domestic homes with roadside, urban and rural locations in a central Indian region, Indoor Air, 15, 76-82.

Lawrence A. and Fatima N. (2014), Urban air pollution and its assessment in Lucknow city-the second largest city of north India, Science of the Total Environment, 1, 488-489.

Lippmann M. (1998), The 1997 USEPA standards for particulate matter and ozone, In Issues in environmental science and technology, Hester R.E. and Harrison R. (eds.), Royal Society of Chemistry, U.K., 10, pp. 75-99.

Mac. (2009), Indoor Air Pollution Create Problems for Rural Areas. http://www.lifeofearth.org

ORAQI. (1970), Oak Ridge Air Quality Index. In Environmental indices theory and practice, Ott W.R. (ed.), Ann Arbor Science, Mich.

Masih A., Lall A.S., Taneja A. and Sanghvi R. (2017), Exposure profiles, seasonal variation and health risk assessment of BTEX in indoor air of homes at different microenvironments of a terai province of northern India, Chemosphere, 176, 8-17. 
Masih A., Lall A.S., Taneja A. and Singhvi R. (2016), Inhalation exposure and related health risks of BTEX in ambient air at different microenvironments of a terai zone in north India, Atmospheric Environment, 147, 55-66.

Mohamed S., Werner B., Fiedler M., Müller H.-J, Gläser M., Christian A., Brunsch R., Loebsin C., Tober O. and Sanftleben P. (2011), Implementation of Radioactive $85 \mathrm{Kr}$ for Ventilation Rate Measurements in Dairy Barns, DOI: 10.13140/RG.2.1.2701.9684.

Mohapatra I., Das S.C. and Samantaray S. (2018), Health impact on women using solid cooking fuels in rural area of Cuttack district, Odisha, Journal of Family Medicine and Primary Care, 7, 11-15.

Mudway I.S., Stenfors N., Duggan S.T., Roxborough H., Zielinski H., Marklund S.L., Blomberg A., Frew A.J., Sandström T. and Kelly F.J.(2004), An in vitro and in vivo investigation of the effects of diesel exhaust on human airway lining fluid antioxidants, Archives of Biochemistry and Biophysics, 423, 200-212.

Mudway I.S. and Kelly F.J. (1998), Modelling the interactions of ozone with pulmonary epithelial lining fluid antioxidants, Toxicology and Applied Pharmacology, 148, 91-100.

Mukkannawar U., Kumar R. and Ojha A. (2014), Indoor Air Quality in Rural Residential Area - Pune Case Study, International Journal of Current Microbiology and Applied Sciences, 3, 683-694.

Neogi S.B., Pandey S., Sharma J., Chokshi M., Chauhan M., Zodpey S. and Paul V.K. (2015), Association between household air pollution and neonatal mortality: an analysis of Annual Health Survey results, India, WHO South-East Asia Journal of Public Health, 4(1), 30-37.

Pant P., Guttikunda S.K. and Peltier R.E. (2016), Exposure to particulate matter in India: A synthesis of findings and future directions, Environmental Research, 147, 480-496.
Rao H.V.N. and Rao M.N. (2001), Air pollution, Tata McGraw-Hill Publishing Company Ltd., New Delhi.

Rees N. (October 2016), Clear the air for children: The impact of air pollution on children, UNICEF p. 34.

Rios J., Vedal S. and Pare P. (2004), Exposure to biomass smoke and chronic airway disease in Mexican women, American Journal of Respiratory and Critical Care Medicine, 154, 701706.

Singh A.L. and Jamal S. (2012), A study of risk factors associated with indoor air pollution in the low income households in Aligarh city, Indian Journal of Environmental Research Management, 3, 1-8.

Singla V., Pacharri T., Satsangi A. et al. (2012), Comparison of BTX profiles and their mutagenicity assessment at ttwo sites of Agra, Indian Science World, J11, 1-11.

Taneja A. and Lawrence A. (2005), An Investigation of Indoor Air Quality in Rural Residential Houses in India- A Case Study. Indoor and Built Environment, 14, 321-329.

Tiwari T.N. and Ali M. (1987), Air Quality Index for Calcutta and its monthly variation for various localities, Indian Journal of Environmental Protection, 7, 172-176.

The 2016 Environmental Performance Index.

Thurston G. and Balmes J. (2017), We need to "think different" about particulate matter, American Journal of Respiratory and Critical Care Medicine, 196 (1), 6-7.

Veena J., Chandra V. and Ahuja D. (2005), Emissions from burning bio fuels in metal cook stove, Environmental Management, 763-772.

Xing Y.F., Xu Y.H., Shi M.H. and Lian Y.-X. (2016), The impact of PM2.5 on the human respiratory system, Journal of Thoracic Disease, 8, E69-E74, DOI:10.3978/j.issn.20721439.2016.01.19

Zhang J. and Smith K.R. (2003), Indoor air pollution. A global health concern, British Medical Bulletin, 68, 209-225. 